\title{
ネコの非律動的不随意運動発現 に関与する神経路に関する研究
}

\author{
Study of the neural pathway concerned with \\ the non-rhythmic involuntary movements in cats.
}

\author{
岡山大学医学部脳神経外科教室（主任：西本 詮教授) \\ 吉村 好 和 \\ （昭和57年12月 21 日受稿）
Key words: dyskinesia, mesencephalic
vertromedial tegmentum(VMT),
Kainic acid

\section{緒言}

Parkinsonismに対し, Cotzias ら (1967 $)^{1)}$ が L-Dopa の大量投与の有効性を報告して以来, その画期的な治療効果によって, L-Dopa 療法 が広く普及するに至っている。さらに近年, L-Dopa と末梢性脱炭酸酵素阻害剂を併用する ことにより，少量の L-Dopa で脳内 dopamine （以下 DA と略す）濃度を高め, DAの末梢性副 作用を軽減させる試みがなされ，優れた臨床効 果が得られるようになった。しかしその反面, L-Dopa 療法の副作用としての顔面, 口・舌や 四肢. 体幹にみられる L-Dopa induced dyskinesia $^{2-4)} の$ 出現頻度が增加し, 併用療法が行 われた Parkinsonism の50ー90\%の例に L-Dopa induced dyskinesia の発生がみられるに至って いる5,6).この L-Dopa induced dyskinesia は 症候学的には chorea に極めて類似した不随意 運動であり，その発現機構の解明は治療の点か らも, また, 錐体外路系の病態生理を知る上か らも, 重要な課題となっている. Parkinsonism は黒質線状体 DA ニューロンを中心としたアミ ン代謝障害がその本態であるとされているが7 10), この L-Dopa induced dyskinesia や chorea は いずれも線状体がその症状発現の場として主要 な役割を占めているのであろうと考えられてい る11-13). 線状体においては, DA, acetylcholine, 5-hydroxytryptamine (以下 5-HT と略す), gamma-amino-butyric acid (以下 GABA と略 す)などを neurotransmitter とする種々の二ュ 一ロンが存在するが, これらの間のバランスが 崩れて、DA が減少すれば akinesia を主とした Parkinsonism の症状を呈し, 逆にDA が過剩とな るとdyskinesiaという運動光進状態を呈すると考 えられている。すすなわち，Parkinsonismにおける L-Dopa induced dyskinesia は線状体 DA レセ プターの denervation supersensitivity ${ }^{14)}$ が存 在する状況において，L-Dopa を大量負荷する ことによって生じるのであろうと推測されている.

一方, この L-Dopa induced dyskinesia とよ く類似した abnormal involuntary movement （以下 AIM と略す）をサルやネコを用いて実験 的に作成し ${ }^{15-21)}$, dyskinesiaにおける神経生 理学的, 神経化学的検索を進める試みがなされ ているが，未だ統一した見解が得られていない， そこで, 本研究では, ネコの中脳内腹側被蓋 野 (ventromedial tegmentum-以下VMT と 略す）に刺激用電極を埋め込み，その高頻度電 気刺激により AIM を誘発21)せしめた上で, glutamic acidの構造類似物である kainic acid (以下 KA と略す) (図 1 ) を尾状核頭部(head of caudate nucleus一以下 $\mathrm{HCN}$ と略す)，被款， 淡蒼球 (globus pallidus一以下 GP と略す) に 微量注入して破壊巣を作成し，AIMに及は寸影 
<smiles>NC(CCC(=O)O)C(=O)O</smiles>

Glutamic Acid<smiles>C=C(C)C(CNC(C(=O)O)C(=O)O)CC(=O)O</smiles>

Kainic Acid

図 1 Glutamic acid および Kainic acid の構造式

響を観察するとともに，その発現に関与する忆 経路について検索を行った.

\section{実 殹方 法}

\section{第 1 節 電極埋め込み実験}

体重2.5〜3.5kgの比較的よく慣れた成熟ネ コ27頭を用いた。硫酸アトロピン $0.03 \mathrm{mg} / \mathrm{kg}$ を前投薬として筋注し、塩酸ヶタミン $15 \mathrm{mg} / \mathrm{kg}$ を麻酔剤として筋注により使用し，自発呼吸下 に実験を行った. 東大脳研式定位頭蓋固定器に 頭蓋を固定し，air drill を用いて小孔を穿ち， Snider-Niemer の図譜22)に従って,一側の VMT (A: 4.0 4.5, L : 2.0 2.5, H: -5 - 5.5〕に 外径 $0.5 \mathrm{~mm}$, 電極間距離 $1 \mathrm{~mm}$ のステンレス製 同心円双極電極を刺入した，先端部の双極電極 の高頻度電気刺激 $(3 \sim 10 \mathrm{~V}, 0.5 \sim 1.0 \mathrm{msec}$, 20〜100 Hz) によって刺激側瞳孔の縮曈, 眼球 の内転, 瞬膜の収絔, 項頸筋の収縮のほか, ロ・ 舌, 反对側肢のchorea 梯不随意運動の出現 を認めたが、これらの刺激効果が最も著しい部 位に，歯科用セメントを用いて電極を頭蓋に固 定して慢性実験用とした。

第 2 節 電気刺激実験

刺激実験は電極の埋め込み手術後 4，5 日を 経過して全身の状態が安定したと思われる時期 以降に，無麻酔下に無抑制の状態で，電極にコ 一ドを接続し, 日本光電製 electronic stimulator MSE-3R を用い, $3 \sim 10 \mathrm{~V}, 0.5 \sim 1.0 \mathrm{msec}$, $20 \sim 100 \mathrm{~Hz}$ の矩形波で, VMT の電気刺激を行
い,その刺激効果を観察した。

第 3 節 視床腹外側核破壊実験

VMT に電極を埋め込み，その電気刺激によ って再現性のよいAIM が誘発されることを確 認した 1 頭のネコ（Cat No4）の，電極を埋め 込んだVMTと同側の視床腹外側核〔 $\mathrm{A}: 10.0$, $\mathrm{L}: 5.5, \mathrm{H}:+3.5\}$ に破壊巣を作成した。前投 薬として硫酸アトロピン0.03mg/ $\mathrm{kg}$ を筋注し, 麻酔剂として塩酸ヶタミン $15 \mathrm{mg} / \mathrm{kg}$ を筋注によ ク使用し，気管内挿管による調節呼吸下に，頭 蓋に air drill を用いて小孔を穿った。凝固針先 端を目標部に刺入し, Stoelting 社製直流式 Lesion Producing Device を用いて, 電極先端を 陽極とした単極法により，5 mA，10 sec の高 周波電気凝固を行って破壊巣を作成し, 視床腹 外側核破壊後の VMT 刺激による効果を観察した。 第 4 節 KA 注入実験

VMT に電極を理め込み，その電気刺激によ ク AIM を誘発せしめたネコ16頭を用いて，以 下の部位に KA を微量注入して，小破壊巣を作 成した。

(1) HCN. anteroventral part (A: $17 \sim 19$, $\mathrm{L}: 4 \sim 5, \mathrm{H}:+4 \sim+5$ ) (Cat No. 5,6)

(2) $\mathrm{HCN}$. rostromedial part (A: $14 \sim 15$,

$\mathrm{L}: 4 \sim 5, \mathrm{H}:+4 \sim+5$ ) (Cat No. 9, 22)

(3) 被款 $(\mathrm{A}: 9-18.5, \mathrm{~L}: 8 \sim 12.5, \mathrm{H}:$ $0 \sim+1.5$ ) (Cat No. 24, 28, 35, 36)

(4) GP [A: $10 \sim 13.5, \mathrm{~L}: 9 \sim 10, \mathrm{H}: 0\}$ (Cat No. 13, 14, 15, 17, 19, 21) 
(5)entopeduncular uncleus $(\mathrm{A}: 11.5, \mathrm{~L}$ : 6.5, H : -1.5) (Cat No. 25, 33) GPにKA を注入したネコ 6 頭のうち， 3 頭 (Cat No. 13, 19, 21) ではGPの medial part のみに、また, 1 頭 (cat No. 17) では GP の lateral part のみに限局した破壊巣を作成 すへく試みた。

KA は石津製薬K.K.製のものを用い，生食 1 $\mathrm{ml}$ に $\mathrm{KA} 2 \mathrm{mg}$ を溶解してその溶液 $1 \mu \mathrm{l}$ (KA として $2 \mu \mathrm{g})$ を各部位に注入し, 注入部位の神 経細胞が十分に破壊されたと思われた 7 ないし 10 日目以後に, VMT 刺激を行って運動効果を 観察した。

第 5 節 組織学的検索

視床腹外側核に高周波電気凝固による破壊巣 を作成したネコ（cat No. 4)）および，線状体 の各部位に KA を微量注入して破壊巣を作成し たネコ9頭（cat No.6，14，15，21，22，25， $28 ， 33 ， 35 ） に つ き$, 破壊巣作成後の VMT 刺 激による刺激効果を観察した後，硫酸アトロピ ン $0.03 \mathrm{mg} / \mathrm{kg}$ を前投薬として用い, 塩酸ヶ夕ミ ン $15 \mathrm{mg} / \mathrm{kg}$ 筋注による麻酔を行い, 気管内㨉管 による調節呼吸下に開胸を行って、胸部大動脈
を露出し，カテーテルを挿入して，10\%ホルマ リン溶液500～1000ml にて脳を灌流した。断頭 後, 脳を取り出し, 10\%ホルマリン溶液中に浸 し, 3 週間固定した後，視床腹外側核破壊を行 ったネコにおいては，前額断による厚さ50 連続切片を作成して破壞巣を確かめ, KA 注入 実験を行ったネコにおいては，厚さ $5 \sim 10 \mu の$ 連続切片の Hematoxylin-Eosin 染色, および, Klüver-Barrera 染色によって,KA による破壊 巣の部位, 組織学的変化につき検討した。

\section{実 医 結 果}

第 1 節 VMT の刺激効果

27頭の成熟ネコの一側 VMT〔A：4〜4.5, $\mathrm{L}: 2 \sim 2.5, \mathrm{H}:-5 \sim-5.5$ ) (図2) に電極を 埋め込み, 3 10V, $0.5 \sim 1.0 \mathrm{msec}, 20 \sim 100$ $\mathrm{Hz}$ の高頻度電気刺激を行った。刺激直後に随意 連動の停止と, 刺激側曈孔の縮曈, 眼球の内転 がおこり，2 ないし 4 秒の潜時をおいて頭部お よび体幹の刺激反对側への turning，続いて反对 側前肢の挙上，または招き様運動，chewing， licking を生体としたロ・舌のAIMが観察され, さらには salivation, urination, tachycardia

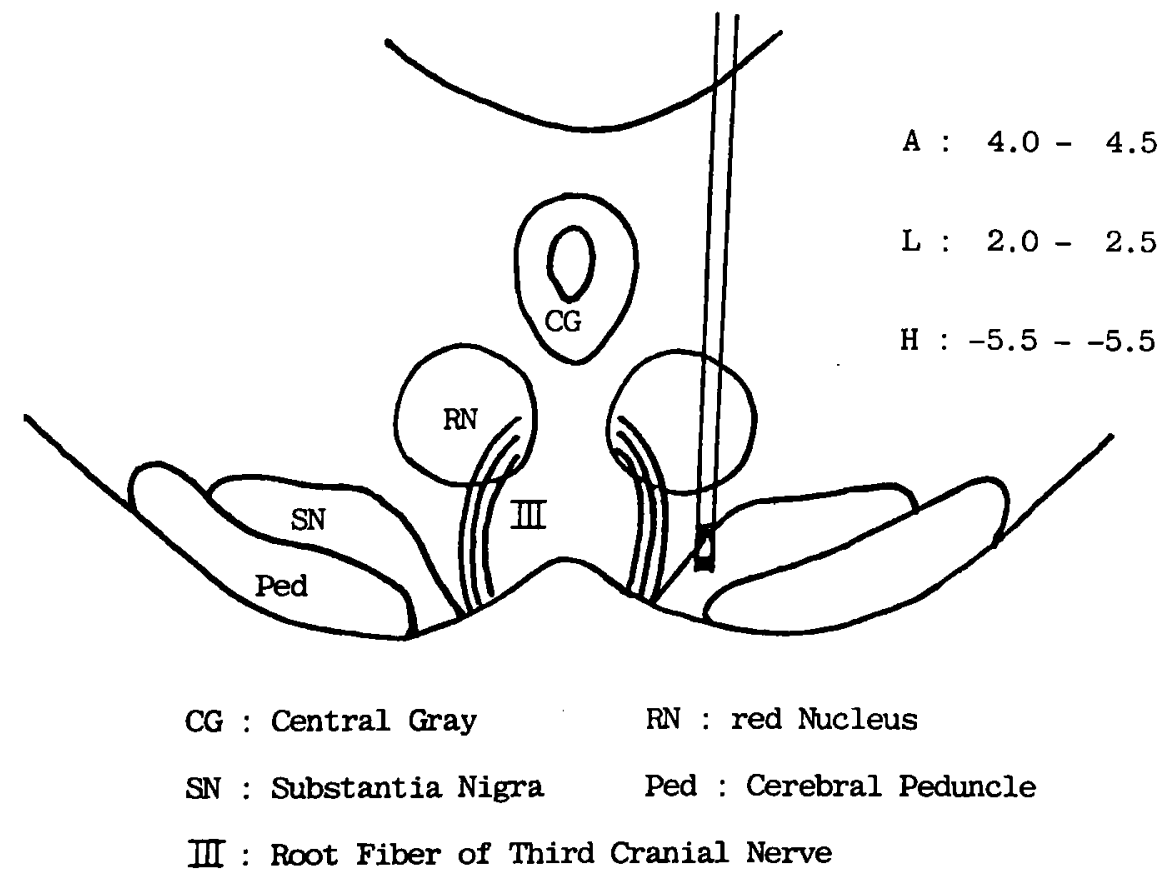

図2 VMTへの埋め込み電極の位置を示す模式図 
などの自律神経症状の発現も認められた。これ らの AIM は刺激中持続して観察され，刺激中止 後も数秒間続いて認如れた。このような典型 的な刺激効果を呈したものは27頭のうち17頭で あり，他の10頭においては，刺激効果は認めら れたものの，AIM が軽度で典型的でないもの3 頭, 反対側への turning のみ呈したもの 3 頭, ロ・舌の chewing, licking などの bucco-lingual movement が主体であったもの2 頭, 反 対側前肢の AIM しか呈さなかったもの 2 頭で あった。これらの刺激効果は同一のネコにおい て, 電気刺激のくり返しによって同じ不随意運 動が再現されるのが観察された。

第 2 節 視床腹外側核破壊の効果

VMT 電気刺潡により，刺激反対側への turning, 口・舌の chewing, licking, 反对側前肢の 招き様運動などの典型的な刺激効果を呈したネ ב 1 頭（cat No. 4 ）を用い,VMT刺激と同側 の視床腹外側核に高周波電気凝固による破壊巣を 作成し，4 日目以後にVMT の電気刺激を行った。 VMT 刺激により，刺激側瞳孔の縮瞳，眼球の 内転は認められたが，刺激反射側への turning，

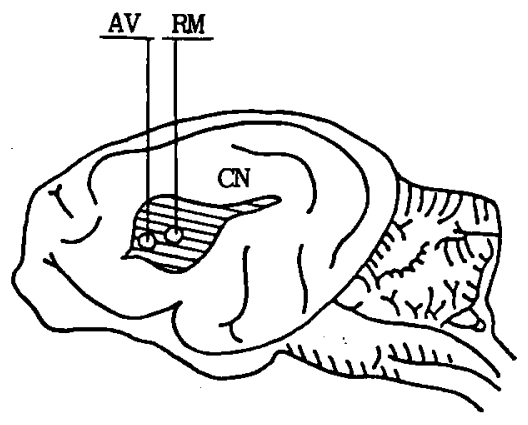

$\mathrm{CN}$ : Caudate Nucleus

AV : Anteroventral Part

RM : Rostromedial Part
ロ・舌の chewing, licking, 反对側前肢の招き 様運動などの AIM は認められす，周波数は20 $\sim 100 \mathrm{~Hz}$ の範囲で, 刺激電圧を $15 \mathrm{~V}$ まで上昇さ せても AIM の出現はみられなかった。

第 3 節 $\mathrm{KA}$ 注入後の VMT 刺激効果

図 3 の如く, HCN $の$ anteroventral part (A: 17 19, L: 4 5, H: +4 +5) (Cat No.5, 6)，および, 被殼[A : 9 18.5, L:8 12.5, H:0 土1.5] (Cat No. 24, 28, 35, 36) に KAによる破壊巣を作成したネコにおいては， 破壊後もVMT 刺激による chewing, licking な どの bucco-lingual movement や反对側前肢の AIM は破壊前と同㥞に認められ，破壊による VMT 刺激効果に変化はみられなかった。一方, HCNの rostromedial part 〔A: 14 15, L : 4 5, 4:+4〜+5) (Cat No. 9, 22), および, GP (A : 10 13.5, L : 9 10, H:0] (Cat No. $13 ， 14 ， 15 ， 17 ， 19 ， 21 ）$ を破壊したネコにお いては，破壊後にVMT 刺激による AIM は消 失した。 また, entopeduncular nucleus (A : 11.5, L : 6.5, H : - 5] (Cat No.25, 33)の みに限局した破壊巣を作成すへくく $\mathrm{KA}$ 注入を
AV

A : $17-19$

L : $4-5$

$\mathrm{H}: 4-5$

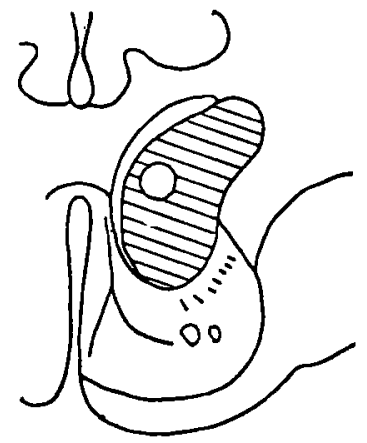

$\mathrm{RM}$
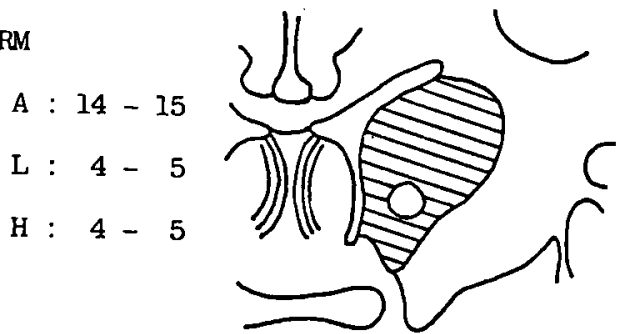

四 3 尾状核内 $\mathrm{KA}$ 注入部位を示す模式図 


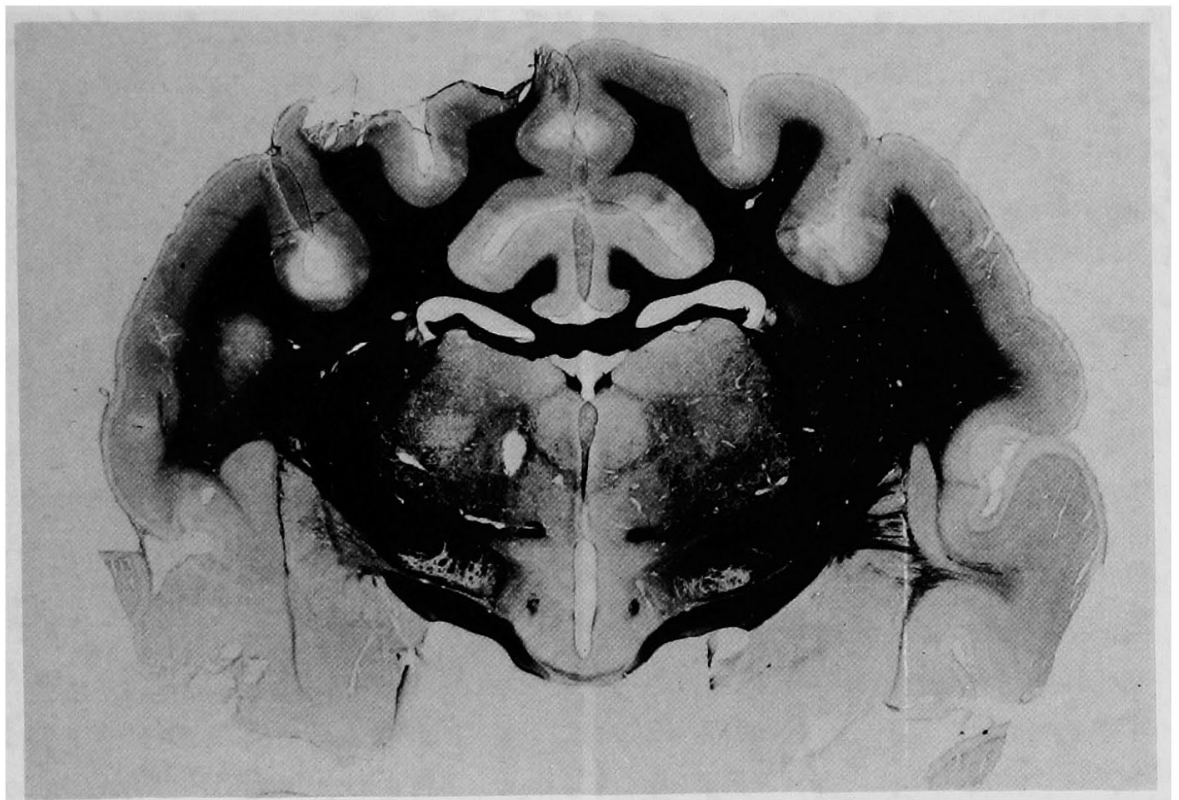

図 4 視床腹外側核破壊巣（前額断）

(Kliviver-Barrera 染色)

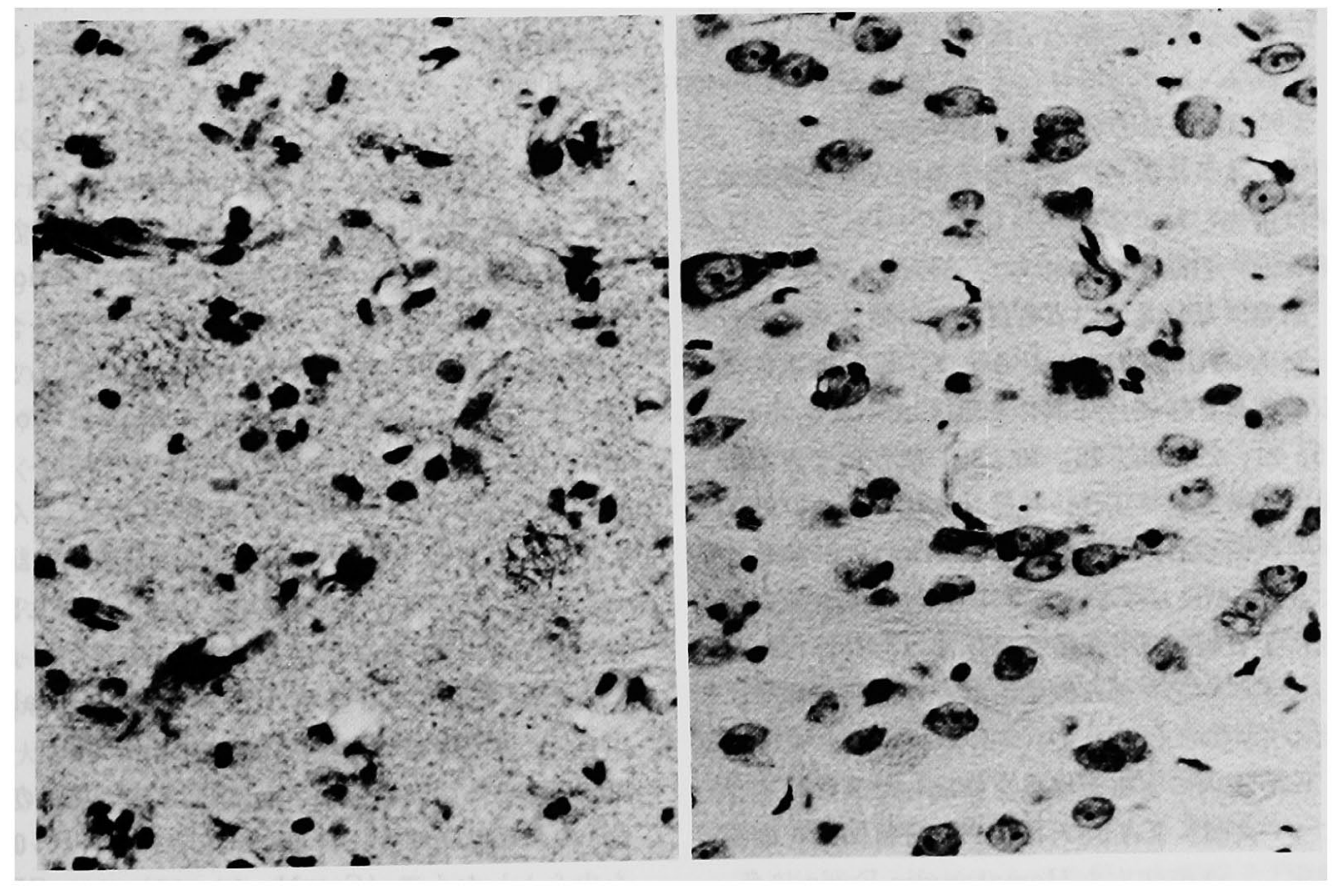

园 $5 \mathrm{HCN}$ rostromedial partへの KA 注入による組織変化

(左：注入部

右：隣接する HCN 正常組織像

(Klüver-Barrera 染色. 200倍) 


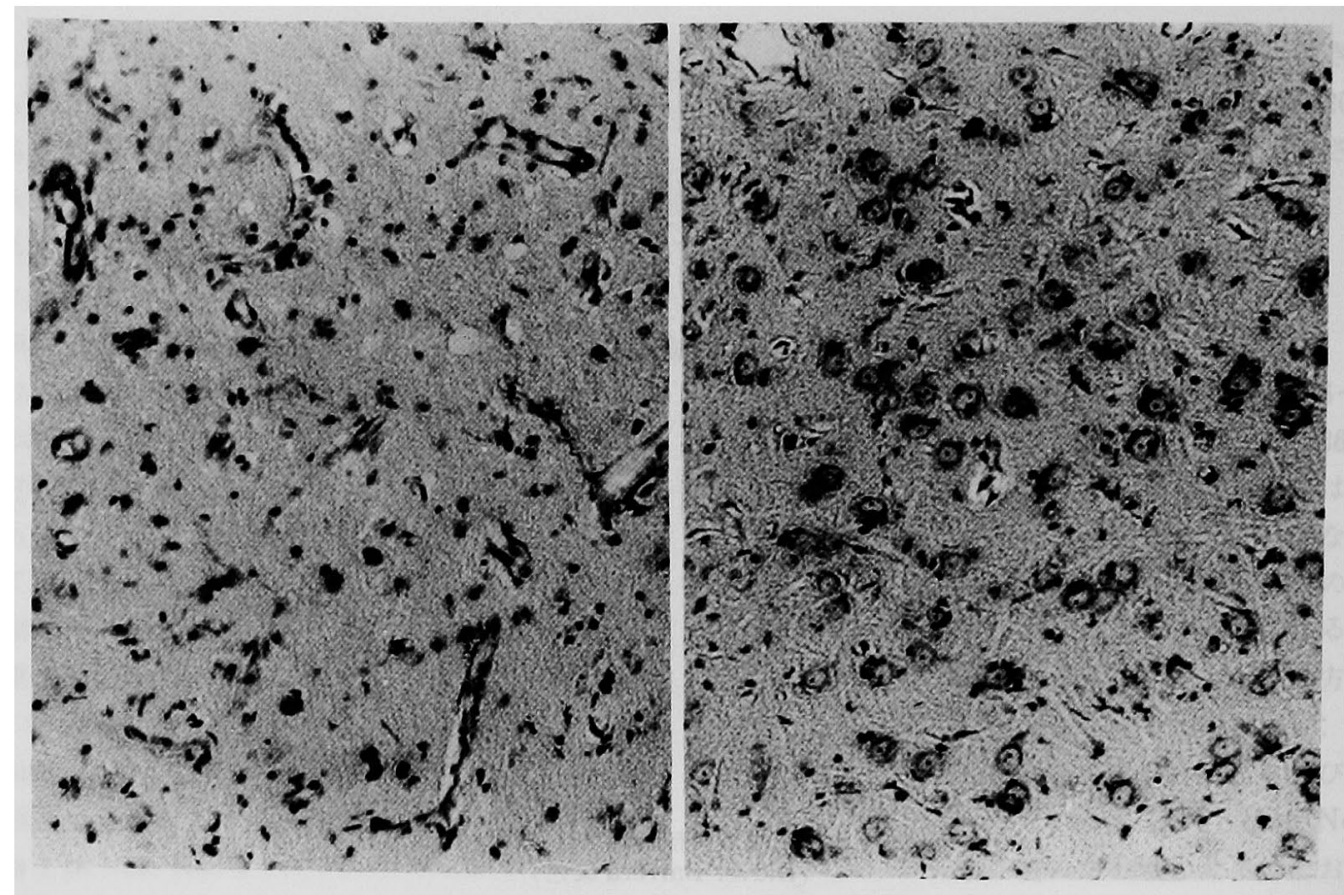

図6. GPへの KA 注入による組織変化

(左：注入部

右：隣接する GP 正常組織像

(Klüver-Barrera 染色. 100倍)

行ったネコにおいては，破壊後にVMT 刺激効 果は消失した。

第 4 節 組織学的検索

高周波電気凝固に上る視床腹外側核破壊を行 つたネコ(Cat No. 4)，およU゙，KA 注入によ る破壤巣を作成したネコ9頭(Cat No. 6, 14， $15,21,22,25,28,33,35)$ について,VMT 電気刺激実験終了後，連続切片標本により破壊 巣を確認した，目 4 は Klüver-Barrera 染色に よる前額断における視床腹外側核の高周波電気凝 固による破壊巣である，破壊巣は腹外側核の殆 んどすへてとと一部外㑡中心核，後内側腹側核に 及んでいた。

$\mathrm{KA}$ 注入による破壤巣を作成した 9 頭のネコ については, KA 注入後12〜15日目に脳を灌流 固定し，連続切片を Hematoxylin-Eosin 染色, および, Klüver-Barrera 染色によって, 破壊巣 を確認した，HCNにおいては，それぞれ HCN 内で anteroventral part (Cat No. 6 ), rostromedial part (Cat No. 22) によく限局した破壊
巣を認めた。被㲄では，その anteriorで〔A： 16, L：8，H：0] の部を中心としてKA を注 入したネコ(Cat No. 28) では被殼の anterior part のほとんどすべてと一部内包, 外包,前障を含 む破壊巣を認め,その posteriorで[A：10.5, L : 11.5， H：0) の部を中心としたもの (Cat No. 35）では, 被款の posterior partでそのdorsal part と ventral partの一部を除いたほとん どすべてと外包，前障を一部含んだ破壊巣を認 めた. GPにおいてはその medial part 〔A : 11.5, $\mathrm{L} ：$ 9.0 $, \mathrm{H}: 0]$ を中心として KA 注入を行っ たもの (Cat No. 21) では GPの dorsolateral part を一部除いたすべてと entopeduncular nucleus の外側 $2 / 3$, 内包の一部を含む破壊巣が, GP の lateral part $[\mathrm{A}: 11.5, \mathrm{~L}: 10.0, \mathrm{H}: 0]$ を中心としたもの（Cat No. 14，15）では,GP の ventromedial part を除くほとんどすべてと 一部被殻内側, entopeduncular nucleus $の$ dorsolateral part, 内包を含む破壊巣が認められた。 entopeduncular nucleus $[A: 11.5, L: 6.5$, 
H: -0.5) (Cat No. 25，33)においては，破壊 巣は entopeduncular nucleus $の$ 内側 $1 / 3$ を除い た部分と, GP の内側 $2 / 3$, 内包の一部を含んだ 破壊巣を認めた。このように, HCN において はその anteroventral part, rostromedial part に限局した破壊巣を作り得, 被設においても， $\mathrm{KA}$ 注入部位を変えることにより，被噎のほと んどすべての部を破壊し得たが，GP において その medial part または lateral part のみに限 局した破棲巣，および, entopeduncular nucleusのみに限局した破壊宩を作成することは成 し得なかった。本研究では KA $2 \mathrm{mg}$ を生食 1 $\mathrm{ml}$ に溶解し，その溶液 $1 \mu \mathrm{l}$ (KA として $2 \mu \mathrm{g})$ を注入したが、いずれの例においても良く限局 された直径2.6〜3.0mm の球状の破壤巣を作成 し得た. 目 5 左は $\mathrm{KA}$ を注入した HCN の rostromedial part $の$ Klüver-Barrera 染色によ る200倍の光顕組織像，図 5 右は同部に隣接した HCN の正常組織像である. KA 注入部位にお いては, 血管增生, 細胞消失などの変化がみら れるが, myelinはよく保たれており, 通過線維 には影響を与えないことを示していた，図6左 は KA 注入部位の GP medial part の KlüverBarrera 染色による100倍の光顕組織像であるが, HCN におけると同様の組織変化が認められた. 图6 右は同部に隣接した GP の正常組織像であ る。いずれの例においても, 破壊巣と正常組織 との境界部は崩壊した神経細胞が正常組織内に わずかに認められるという形を示し，破壊巣は よく限局されていた。

\section{考按}

Parkinsonismにおいては，線状体における DAの減少に基づくDAレセプターの denervation supersensitivity $^{14,23)}$ が存在し、そこに L-Dopa の大量投与による DAの過剩状態が生じると, L-Dopa induced dyskinesia が発現するとされ ている12,14).一方, この L-Dopa induced dyskinesia と症候学的に類倾した Huntington's choreaにおいては, 黒質細胞に对して抑制的に 働く尾状核の GABA ニューロンの著明な変性脱 落13,24)のために，脱抑制による黑質線状体 DA ニューロンの hyperfunction が生して, 変性過
程にあって abnormal response を呈する線状体 ニューロンにDAが作用し， chorea を発現する ものとされている12)

すなわち, dyskinesia や chorea などの本態 は線状体 DAレセプターの supersensitivityや， 線状体 DA の過剩, DA ニューロンの hyper-

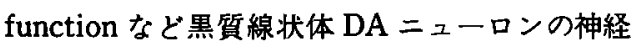
化学的異常であるとされているが、その発現機 序および神経路に関しては未だ推測の域を出ず, 統一した見解が得られていないのが現状である。

ところで, 現在, このヒトの L-Dopa induced dyskinesia によく類似した AIMを呈する実 験モデルを使用して, 種々の神経化学的, 神経生 理学的検索がなされている25 29). Goldstein らは サルの一側VMTに小破壊巣を作成し，反対側肢 の hypokinesia と自発性振戦を呈したサルにLDopa を負荷すると, 振戦の停止と同時に振戦肢, 顔面・ロ・舌の choreo-athetosis 様の AIM が

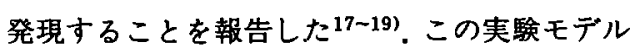
においては、VMT破壊により、この部を通る 黑質線状体 DA ニューロン, 縫線核線状体 5HT ニューロンの切断と, 背側縫線核の細胞消 失, お上び赤核脊剈路と結合腕腹側部の破壊な どが生じるが、この際, 破壊側の線状体におい てDA と 5-HT の著明な減少が認められている ${ }^{18,300}$. 一方, Lilesら(1969)15)はネコの HCNの破壊に より,また, Skultety $(1962)^{31)}$, 中村 $(1980)^{21)}$ らはネコのVMT 刺激により head turning, circling, choreo- athetosis 様の AIM を誘発せし め得ることを報告している，中村はこのVMT 刺激によって誘発される AIM はVMT の電気 刺激によって線状体ニューロンの hyperfunction が生じて超こるのであろうと考察している21!. これら二種類の動物を用いた実験モデルにおい て, 極めて類似した不随意運動が誘発されてい るが, Goldstein らのサルを用いた実験におい て，VMT の破壊によって線状体のDAレセプ ターに起きた変化の上に L-Dopa を負荷したの と同じ状態が，中村のネコを用いた実験モデル におけるVMT 刺激で得られるのではないかと 考えられ，いずれにおいても同じ機序で不随意 運動が発現しているものと思われる。ところで, 
一㑡 VMTに破壊巣を作成した後，L-Dopa の 大量投与によって誘発されるサルの dyskinesia はVMT 破壊側と同側の視床腹外側核破壊によ って消失することが確かめられており 17 19)、こ の AIM 発現機構には，黒質線状体から視床に 至る神経路が主要な役割を果たしていると考え られているが,この神経路の詳細な fiber connectionに関しては末ジーした見解が得られて いない.

一方，近年，グルタミン酸の構造類似物であ る $\mathrm{KA}^{32)}$ がその脳内微量注入により, 注入部位 において，通過線維および神経終末に何ら影響 を与えることなく，選択的に神経細胞体および その樹状突起を破壊する33,34) という特性を利用 して, 種々の神経化学的, また, 神経生理学的 検索に応用されるようになってきた年〜39).KA 注入後の組織変化については，まず，KA 注入 10 分後には細胞質内のNissl-substanceの減少が はじまり，約 2 時間後にはこの変化の進行とと もに細胞体が丸味を失ってその構造に変化が生 じささらに時間経過につれて，核の好塩基性が 增強し, クロマチンの凝集が著明となり, nuclear membrane $の$ distortion, 細胞質の焚胞化 が起こク，24時間後には neuron はその径が40 \%にまで減少する。注入後 2 日を経過すると， 細胞質内のNissl-substanceの消失, 細胞体の著 明な減少，クロマチンの凝集，および, nuclear membrane の断裂, 崩壊が生じ, 注入 7 ないし10日後には注入部位の著明な細胞消失, 毛細血管の増生, グリア細胞の增殖が認められ, 注入後 3 週間では著明な astrocyte の增生を生 じてくるとされている33)。また，KA 注入では 急性期の変化としての血管に対する傷害やそれ に伴う出血, あるいは細胞の炎症性反応は認め られないときれている33). KA 注入量と破壊巣 の大きさとの間には直線的な相関関係は認めら れないが、いずれも生食 $1 \mu 1$ の溶液とした場合 には, KA $0.5 \mu \mathrm{g}$ で直径 $0.4 \sim 0.6 \mathrm{~mm}, 1.0 \sim 2.0$ $\mu \mathrm{g}$ で直径 $2.6 \sim 3.0 \mathrm{~mm}, 5 \mu \mathrm{g}$ では直径 3.2 3.6 $\mathrm{mm}$ の球状を呈する破壤巣の作成がみられると されている33).

そこで本研究では黒質背内側部を含めたVMT に電極を埋め込んだ慢性ネコを使用して，その
電気刺激により AIM を誘発せしめ,さらに VMT 刺激と同側の視床腹外側核破壊によって, 破壊後はVMT 刺激による AIM 発現が消失す ることを確認した上で，それぞれ異ったネコを 用いてネコの AIM 発現に関与していると思わ れる尾状核, 被殻, 淡蒼球の各部に KA を微量 注入し, 注入部位の細胞体および樹状突起破壊後の VMT 電気刺激によるAIM 発現の有無を検討しここ のネコにおけるAIM 発現に関与する神経路に ついて検索を行った。

HCN anteroventral part, 被款への KA 注 入による破壊巣作成では, 注入後のVMT 電気 刺激による AIM 発現に変化は認められなかっ たが, HCN rostromedial part, GPへの KA 注入では，注入後の VMT 電気刺激によるAIM 発現の消失をみた. entopeduncular nucleus への KA 注入でも，AIM 発現の消失を認めたが, 実験後の連続切片による組織学的検索では, 破 壊巣は実際には entopedunclear nucleus のみ ならず GPの大部分をも含んでおり，entopeduncular nucleus のみに限局した破壊巣は作り 得なかった。細織学的には各々の注入部位にお いて，通過線組は影響を受けることなく，よく 限局した直径 $2.6 \sim 3.0 \mathrm{~mm}$ の細胞消失を主体と した破壊巣が認められた。すなわち，ネコにお いては, AIM を発現する神経路は黒質線状体路 から $\mathrm{HCN}$ rostromedial part, GP, 視床腹外側核に 至る経路が主要な役割を果しており，このうち， HCN rostromedial part, および, GP におい て少なくとも 1 つ以上のシナプスを経由してい るものと考えられた。しかしながら，淡蒼球内 における機能の局在，さらには，Hassler ら ${ }^{40)}$,

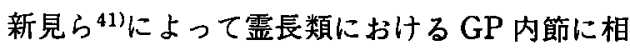
当するとされているネコの entopeduncular nucleus のAIM 発現機構への関与の有無に関し てはなお不明でこれらに関しての検索には本 研究における KA を使用した方法では困難であ ると思われた。

黒質線状体路は黒質 pars compacta の rostral part から $\mathrm{HCN} へ$, caudal partから被款 へ dopaminergic fiber が投射し42 44), HCNに おいて interneuron にシナプス結合をしているの ではないか45)とされているが,この dopaminergic 
fiber が線状体ニューロンに及ほ影響について は，抑制的に作用するという説 $45-47)$ と促通的に 作用するという説45)に分かれ，いまだ統一した 結論は得られていない，線状体黒質路は $\mathrm{HCN}$ から黒質 pars reticulata $の$ rostral part, 被 㪍から caudal part へ投射し42 44), これらは GABA ${ }^{42,43,48 \sim 50)}$, および, Substance $\mathrm{P}^{51,52)}$

を neurotransmitter とすることが明らかにされ ている. GABA ニューロンまたはそれから放出 される GABA は DA ニューロンに対して単シナ プス性に抑制的に作用すると考之られており 53-56) 一方, substance $\mathrm{P}$ に関しては，黒質に電気泳 動的に substance P を注入するとニューロンの 発火頪度が増大するとされている ${ }^{57)}$ 。また， GABAの antagonist である picrotoxin を投与 してGABAによる抑制を妨げた状態で HCN を電気刺激すると，黒質ニューロンには促通効 果が認められ, この促通効果は substance P と 拮抗作用を有する baclofen を投与すると消失す ることより ${ }^{58)}$, substance $\mathrm{P}$ は黒質ニューロン に对して促通性作用を有していると考えられて いる.これらの黒質線状体路, 線状体黒質路の 運動機能における役割に関して, 諸種の研究が なされている. Huntington's chorea において は, subsfance P の減少を示唆する報告52)はあ るものの, substance $P$ の役割については明ら かにされておらず, HCN の GABA ニューロン の著明な変性脱落のために, DA ニューロンに 对する抑制が失なわれ，DA 系の hyperfunction が生じて chorea が出現するとされている12).こ の choreaは Parkinsonismにおける L-Dopa induced dyskinesia と極めて類似しているが, Parkinsonismにおいては線状体内 GABA 濃度の減少, 線状体 GABA レセプターの減少はみられておら す559), 従って Parkinsonism の線状体では GABA 系の機能低下は無いものと考えられる.

すすなわ線状体においては DA 系と関連を持つ GABA ニューロンをはじめとする種々のニュー ロンは dyskinesia の発現に間接的な影響を与え ているにすぎず, L-Dopa induced dyskinesia の発現に関する一義的な役割は線状体 DA 系に 存在するとされている60). Liles ら(1969) ${ }^{15)}$ は ネコの HCN anteroventral partの一側性小破
㙘策では対応側前肢の athetoid and choreiform hyperkinesia が出現するが，HCN の他の部位 の破壊では AIM の出現は認められなかったと 報告している. Cools (1972) ${ }^{16)}$ はネコの $\mathrm{HCN}$ rostromedial partへの DA 局所注入では対応 側前肢の AIM を認めたが, anteroventral part への DA 注入では AIM の出現は認められなか ったと報告し，また，中村211もネコを朋いて， $\mathrm{HCN}$ 内に同様の機能局在の存在することを報 告している21).大本ら $(1981)^{60)}$ は一㑡 VMT破 壊後，L-Dopa 過剩投与により dyskinesia を発 現させたサルの HCN に慢性カニューレを埋め 込み，種々の中枢作用物質を微量注入して dys kinesia 発現の有無を観察した実験において, $\mathrm{HCN}$ の dorsomedial part $(A: 18.0, \mathrm{~L}: 3.0$ —4.0, H: 11.0 12.0] への DA およ゙゙ DA agonist の注入により dyskinesia の発現をみて いるが，それより目標部位が $3 \mathrm{~mm}$ 以上離れた 部への注入では dyskinesia の発現か認められな かったと報告し，HCN における機能局在を示唆 している. 本研究においても，HCN の anteroventral partへの $\mathrm{KA}$ 注入による細胞体破壊で はVMT 電気刺激による AIM 発現の消失が認 められず, rostromedial part の破壊により AIM の消失を認めたことはこれらの報告と 一致し, $\mathrm{HCN} の$ rostromedial part $の$ neuron が DA 系の hyperfunctionによる AIM 発現の key structure をなすものであると思われた。

HCN から視床に至る transmission 系に関し ては，新見ら $(1970)^{411 に よ れ は ゙ ， ネ コ に お い て ~}$ HCN からは大部分は GP の medial partへ, 一 部は lateral part へ投射しており，HCN 内の 局在については，その medial および ventromedial part からは GP のmedial part へ, lateral part からは GP の lateral partへ, さらに, dorsolateral partからは entopeduncular nucleus へ投射しているとされている。一方, Hassler ら(1974) $)^{40)}$ は, ネコにおいて, HCN から GP, entopeduncular nucleus $に$ efferent connectionが認められ，そのうち，ほとんどは GPの背側 $1 / 3$ ，また,少数が entopeduncular nucleus に投射しているとしている。霊長類にお いては, Hassler ら (1979) ${ }^{42)}$ は線状体からの 
efferent systemは黒質以外にも， $\mathrm{HCN}$ ，被撎 両者から GP 外節人, さらに GP 外節から GP 内節および中脳 reticular formationに GABA nergic fiber が投射し, GP 内節から視床腹外側核 に投射していると報告し, Carpenter ${ }^{43)}$ によ れば， $\mathrm{HCN}$, 被殻ともに GP 内節，外節再者人 の投射が認められ，GP からは視床腹外側核, 視床前腹側核人, GP 内節から中脳被蓋, GP 外節から subthalamic nucleus への投射が存在 するとされている，従って，以上をまとめると， HCN からの efferent systemは, ネコにおいて は, 黒質, GP, entopeduncular nucleus へ, 霊 長類においては，黒質，および, GP 外節, あ るいは内節の双方へ投射するとされ，さらに GP から視床腹外側核への fiber connection が存在 するとされている。この HCN から GP を経由 して視床腹外側核に至る系における GP，おるい はネコにおける entopedunclar nucleus の機能 に関しては議論の多い所である，最近の知見で は, 線状体から GP への投射は, 線状体黑質路 と同様に, GABA, およU゙, substance P を伝 達物質とする抑制性と促通性の両者が存在する のであろうと推測されている611.さらに, GPから 視床への投射系に関しては, Frigyesi ら(1971) ${ }^{62)}$ はネコの entopeduncular nucleus の電気刺激 によって，視床腹外側核。正中中心核において, 単シナプス性の興奮性後シナプス電位をみてお $\eta$, 逆に, 宇野 $(1981)^{61}$ は同じ電気刺激によ。 て, 視床腹外側核, 前腹側核において, 単シナプ ス性の抑制性後シナプス電位を記録し，この抑制 ニューロンは GABA を伝達物質とするとして いる.このように, HCN-GP- 視床系に関して は，その神経生理に統一した見解が得られては いないか，本研究においては，ネコのGPへの KA 注入による破壊で, VMT 刺激による AIM 発現の消失をみたことより AIM 発現に関与す る神経路は GPにおいて1つまたはそれ以上の シナプスを経由していることは確実であると思 われる.すなわち，不随意運動に関与する黒質 一線状体一視床路に関して,ネコにおいては, 黒質一線状体 DA ニューロンの hyperfunction は HCN rostromedial part の部のニューロン の活動によりもたらされ,主として, 異常インパルス
の伝達に関与すると考之られる線状体一視床路 は, HCN rostromedial part. および，GPに おいて，少なくとも1つ以上のシナプスを経由 しているものと考えられた. 今後さらに, GP 内での機能局在の有無, また, entopeduncular nucleus の関与について等, 検討を進める必要 があると思われる。

\section{綵括}

一側 VMTに電極を埋め込み，高頻度電気刺 激により種々のAIM を誘発せしめた成熟ネコ を用い，視床腹外側核の高周波電気凝固による 破壊，および，線状体の各部に KAによる破壊 を行って，AIM 発現に関与する神経路について 検討を行った.

1) 1 側 VMT (A:4.0 4.5, L:2 2.5, $\mathrm{H}:-5 \sim-5.5] の 3 \sim 10 \mathrm{~V}, 0.5 \sim 1.0 \mathrm{~m} \mathrm{sec}, 20$ $\sim 100 \mathrm{~Hz}$ の矩形波高頻度電気刺激により, 刺 激直後に随意運動の停止と同側瞳孔の維睲, 眼 球の内転を認め， 2 ないし 4 秒の潜時をおいて 頭部拉よび体幹の刺激反对側への turning, 反对 側前肢の挙上,または choreo-athetosis 様の AIM, chewing, licking 主体とした buccolingual movement が観察され，さらには salivation, urination, tachycardia ととの自律神経 症状をも認めた。これらの AIM は刺激中持続 して認められ，また，刺激効果は同一のネコに おいて再現性のよいものであった。

2) VMT 電気刺激により AIM を誘発せしめ たネコの同側視床腹外側核 $(A: 10.0, L: 5.5$, $4:+3.5$ 〕に高周波電気凝固によって破塆栄を 作成すると, 破壊後はVMT 刺激による AIM は認められなくなった。すなわち，口・舌や四 肢の AIM を発現するインパルスは視床腹外側 核を経由しているものと考えられた。

3）神経毒である KA が通過線維に何ら影䬸を 与えることなく，神経細胞体およびその樹状突 起のみを選択的に破壊するという特性を利用し て, VMT 電気刺激により AIM を誘発せしめ たネコの線状体の各部に KA $2 \mu \mathrm{g}$ を注入し, 破 壞後の VMT 刺激効果の変化を観察した. HCN $の$ anteroventral part $\{A: 17 \sim 19, L: 4 \sim 5$, $\mathrm{H}:+4 \sim+5)$, および, 被殼 (A : 9 18.5, 
$\mathrm{L}: 8 \sim 12.5, \mathrm{H}: 0 \sim+1.5] \frown の \mathrm{KA}$ 注入後は VMT の刺激効果は注入前と同様に認められ, この部は AIM 発現機構に直接の関与はしてい ないと思われた。一方, HCN のrostromedial part $(\mathrm{A}: 14.0 \sim 15.0, \mathrm{~L}: 4.0 \sim 5.0, \mathrm{H}:+4.0$ $\sim+5.0\rfloor$, および, GP〔A: 10.0 13.5, L : 9.0 10.0, $\mathrm{H}: 0$ ) への $\mathrm{KA}$ 注入では, 注入前 に認められたVMT 刺激効果は消失した。す なわち、この両部位の二ューロンは AIM 発現 に重要な役割を担っていると考えられ，また， AIM 発現に関与する神経路は,この両者におい て，少なくとも 1 つ以上のシナプスを経由して いると考えられた。

4 ) 組織学的検索を行い，KA $2 \mu \mathrm{g}$ を注入した 各部位において，KAにより直径 2.6〜3.0mm のよく限局した球状の破壤巣が作成されている ことを認め，同部において，著明な細胞構築の 崩壊を果たしていることを確認した。なお, KA
による破壞宩において, myelinはよく保たれて おり，通過線維注影響を受けていないものと考 之られた。また，視床腹外側核破壊を行ったネ コにおいて，腹外側核に限局した破壊巣を確認 した。

以上のごとく，ネコの一側 VMT 電気刺激に よって発現するAIM の神経機構に関しては， VMT 刺激と同側の黒質から発して, HCN rostromedial part, GP を経由して視床腹外側 核に至る神経路が主要な役割を果たしており， このうち, NCN rostromedial part, および, GP において，少なくとも 1 つ以上のシナプス を有する経路であると考えられた．

稿を終るにあたり，終始笖篤なる御指導と御校閱 を睗った恩師西本 詮教授、ならびに，大本堯史助 教授に深甚なる謝意を表します。

\section{女 献}

1. Cotzias, G.C., Van Woert, M.H. ang Schiffer, L.M.: Aromatic amino acids and modification of Parkinsoism. N. Engl. J. Med. 276, 374-379, 1967.

2. Cotzias, G.C., Papavasiliou, P.S. and zgellene, R.: Modification of Parkinsonism. Chronic treatment with L-Dopa. N. Engl. J. Med. 280, 337-345, 1969.

3. Mones. R.J., Elizan, T.S. and Siegel, G.T.: Analysis of L-Dopa induced dyskinesias in 51 patients with Parkinsonism. J. Neurol. Neurosurg. Psychiat. 34, 668-673, 1971.

4. Hughes, R.C., Polgar, J.G., Weightman, D. and Walton, J.N.: L-Dopa in Parkinsonism and influence of previous thalamotomy. Br. Med. J. 1, 7-13, 1971.

5. 安藤一也、間野忠明，宇尾野公義，横地正之，伊藤 清，大本堯史，水野美邦：Perkinsonism に对する L-Dopa 療法一L-Dopa 単独療法と carbidopa 併用療法の比較検討一日本医事新報. 2752，11-17, 1977.

6. Mars, H.: Modification of levodopa effect by systemic decarboxylase inhibition. Arch. Neurol. 28, 91-95, 1973.

7. Barbeau, A., Murphy, C.F. and Sourkes, T.L.: Excretion of dopamine in disease of basal ganglia. Science 113, 1706-1707, 1961.

8. Barbeau, A.: The pathogenesis of Parkinson's disease: A new hypothesis. Can. Med. Assoc. J. 87, 802-807, 1962.

9. Turner, B.: Handbook of Clinical Neurology Vol. 6 ed. P.J. Vinken and G.W. Bruyn, North-Holland Publ., Amsterdam, pp. 212-217, 1968.

10. Hornykiewicz, O.: Dopamine in the basal ganglia. Its role and therapeutic implications. (including the clinical use of L-Dopa.) Br. Med. Bull. 29, 172-178, 1973.

11. Klawans, H.L., Ilahi, M.M. and Ringel, S.P.: Toward an understanding of the pathophysiology of 
Huntington's chorea. Confin. Neurol. 33, 297-303, 1971.

12. Klawans, H.L. and Weiner, W.J.: Human extrapyramidal disorders. In Models of Human Neurological Diseases. ed. Klawans, H.L., Excepta Medica, Amsterdam, pp. 1-38, 1974.

13. Barbeau, A.: Biochemistory of Huntington's chorea. In Advances in Neurology, Vol. .1, ed. A. Barbeau, T.N. Chase, and G.W. Paulson, Raven Press, New York, pp. 473-516, 1973.

14. Ungersted, U.: Postsynaptic supersensitivity after 6-hydroxydopamine induced degeneration of the nigrostriatal dopamine system. Acta Physiol. Scand. (Suppl.) 367, 69-93, 1971,

15. Liles, S.L. and Davis, G.D.: Athetoid and choreiform hyperkinesias produuced by caudate lesions in the cat. Science 164, 195-197, 1969.

16. Cools, A.R.: Athetoid and choreiform hyperkinesias produced by caudate application of dopamine in cats. Psychopharmacologia (Berl) 25, 229-237, 1972.

17. Battista, A.F., Goldstein, M. and Ogawa, M.: Production of involuntary movements by L-Dopa in monkeys with tegmental lesions. Exp. Neurol. 33, 566-575, 1971.

18. Goldstein, M., Battista, A.F., Ohmoto, T., Anagnoste, B. and Fuxe, K.: Tremor and involuntary movements in monkeys: Effect of L-Dopa and of a dopamine receptor stimulating agent. Science $179,816-817,1973$

19. Goldstein, M., Battista, A.F. and Miyamoyo, T.: Modification of involuntary movements by centrally acting drugs. In Advances in Neurology, Vol.9, ed. D. Calne, T.N. Chase, and A. Barbeau, Raven Press, New York. pp. 299-305, 1975.

20. Poirier, L.T.: Nervous mechanism involved in experimentally ihduced extrapyramidal disturbances. Confin. Neurol. 36, 223-236, 1974.

21. 中村成夫：ネコの錐体外路系に関する神経生理学的研究(第 1 編). 岡山医学会雑誌. 92, 205-216, 1980.

22. Snider, R.S. and Niemer, W.T.: A Stereotaxic Atlas of the Cat Brain. The University of Chicago Press, Chicago., 1961.

23. Pycock, C.J. and Marsden, C.D.: Central dopaminergic receptor supersensitivity and its relevance to Parkinson's disease. J. Neurol. Sci. 31, 113-121, 1977.

24. Perry, T.L., Hansen, S. and Kloster, M.: Huntington's chorea. Deficiency of gamma-amino-butyric acid in brain. N. Engl. Med. 288, 337-342, 1973.

25. Ward, A.A., McCulloch, W.S. and Magonn, H.W: Production of an alternating tremor at rest in monkeys. J. Neurophysiol. $11,317-330,1948$.

26. Poirier, L.J.: Experimental and histological study of midbrain dyskinesis. J. Neurophysiol. 23, $534-551,1960$.

27. 大本堯史：サルにおける奏験的振戦と舞踏病様不随意運動，神経進步，19，592-603，1975.

28. 大本堯史, 松本祐蔵, 中村成夫, 宮本俊彦：L-Dopa induced dyskinesia に関する実験的研究. 脳と神経, $32,161-169,1980$.

29. Mckenzie, G.M. and Viik, K.: Chemically induced choreiform activity. Antagonism by GABA and EEG patterns. Exp. Neurol. 46, 229-243, 1975.

30. Poirier, L.J. and Sourkes, T.L.: Influences of the substantia nigra in the cathecolamine content of the striatum. Brain 88, 181-192, 1965.

31. Skultety, F.M.: Circus movements in cats following midbrain stimulation through chronically implanted electrodes. J. Neurophysiol. 25, 152-164, 1962.

32. Olney, J.W., Rhee, V. and Ho, O.L.: Kainic acid: a powerful neurotoxin analogue of glutamate. Brain Res. 77, 509-512, 1974. 
33. Coyle, J.T., Molliver, M.E. and Kuhar, M.J.: In situ injection of kainic acid: A new method for selectively lesioning neuronal cell bodies while sparring axons of passage. J. Comp. Neurol. 180, $301-324,1978$.

34. Wuerthere, S.M., Lovell, K.L., Jones, M.Z. and Moore, K.E.: A histological study of kainic acidinduced lesions in the rat brain. Brain Res. 149, 489-497,1978.

35. Coyle, J.T. and Schwarcz, R.: Lesion of striatal neurones with kainic acid provides a model for Huntington's chorea. Nature 263, 244-246, 1976.

36. Schwarcz, R, and Coyle; J.T.: Neurochemical sequelae of kainate injection in corpus striatum and substantia nigra of the rat. Life Sci. 20, 431-436, 1977.

37. Dichihara, G., Ollanas, M., Flacco, M.D., Spano, P.F. and Tagliaminte, A.: Intranigral kainic acid is evidence that nigral non-dopaminergic neurones control posture. Nature 268, 743-745, 1977.

38. Schwarcz, R. and Coyle, J.T.: Striatal lesions with kainic acid; neurochemical characteristics. Brain Res. 127, 235-249, 1977.

39. 栗原悦雄, 米田幸雄, 栗山欣弥：ケイニン酸のラット線状体投与に伴う行動と錐体外路系におけるGABA の変化について. 脳研究会会誌, $5,122-123,1979$.

40. Hassler, R.: Fiber connection within the extrapyramidal system. Confin. Neurol. 36, 237-255, 1974.

41. Niimi, K., Ikeda, T., Kawamura, S. and Inoshita, H.: Efferent projections of the head of the caudate nucleus in the cat. Brain Res. 21, 327-343, 1970.

42. Hassler, R., Mundinger, F. and Riechert, T.: Stereotaxis in Parkinson Syndrome. With an Atlas of the Basal Ganglia in Parkinsonism. ed. R. Hassler, Springer-Verlag, Berlin, Heidelberg New York. pp. 2-13, 1979.

43. Carpenter, M.B.: Human Neuroanatomy. seventh edition. The Williams and Wilkins Company. pp. $496-520,1976$.

44. Szabo, J.: Organization of the ascending striatal efferents in monkeys. J. Comp. Neurol. 189, 307-321, 1980.

45. Kitai, S.T., Sugimoto, M. and Kocsis, J.D.: Excitatory nature of dopamine in the nigrocaudate pathway. Exp. Brain Res. 24, 351-363, 1976.

46. McLennan, H. and York, H.: The action of dopamine on neurones of the caudate nucleus. $J$. Physiol. 189, 393-402, 1967.

47. Siggins, G.R.: Electrophysiological role of dopamine in striatum: excitatory or inhibitory. In Psychopharmacology. A Generation of Progress. ed. M.A. Lipton, A. DiMascio and K.F. Killam, Raven Press, New York, pp. 143-157, 1978.

48. Precht, W. and Yoshida, M.: Blockage of caudate evoked inhibition of neurones in the substantia nigra by picrotoxin. Brain Res. 32, 229-233, 1971.

49. Kim, J.S., Hassler, R. and Okada, Y.: Role of gamma-aminobutyric acid (GABA) in the extrapyramidal motor system 2. some evidence for the existence of a type of GABA-rich strionigral neurones. Exp. Brain Res. 14, 95-104, 1971.

50. 吉田允男：大脳基底核の生理学一最近の知見について一. 神経進歩, 17, 157-161, 1973.

51. Kanazawa, I., Emsin, P.C. and Cuello, A.C.: Evidence for the existence of substance P-containing fibers in striato-nigral and pallidonigral pathways in rat brain. Brain Res. 119, 447-453, 1977.

52. 金澤一郎：Huntington's chorec と神経伝達物質. 神経進歩. 21，705-713，1977.

53. Fuxe, K., Andersson, K., Schwarcz, R., Agnati, L.F., Përez de la Mora, M., Hökfelt, T., Goldstein, 
M., Ferland, L., Possani, L. and Tapia, R.: Studies on different types of dopamine nerve terminals in the forebrain and their possible interactions with hormones and with neurones containing GABA, glutamate and opioid peptides. In Advances in Neurology, Vol. 24, ed. L.J. Poirier, T.L. Sourkes and P.J. Bedard, Raven Press, New York, pp. 199-215, 1979.

54. Klawans, H.L.Jr: The pharmacology of extrapyramidal movement disordere. In Monographs in Neural Sciences. Vol. 2, ed. M.M. Cohen and S. Karger, pp. 98-105, 1973.

55. Yoshida, M. and Precht, W.: Monosynaptic inhibition of neurones of the substantia nigra by caudatenigral fibers. Brain Res. 32, 225-228, 1971.

56. Yoshida, M., Ravin, A. and Anderson, M.: Monosynaptic inhibition of pallidal neurones by axon collaterals of caudatonigral fibers. Exp. Brain Res. 15, 333-347, 1972.

57. Walker, R.J.' Kemp, J.A., Yajima, H., Kitagawa, K. and Woodruff, G.N.: The action of substance $P$ on mesencephalic reticular and substantia nigral 'neurones of the rat. Experientia 32, 214-215, 1976.

58. Kanazawa, I. and Yoshida, M.: Electrophysiological evidence for an existence of the excitatory fibers in the caudate-nigral pathway in the cat. Neurosci. Lett. 20, 301-306, 1980.

59. Rinne, U.K., Sonninen, V. and Laaksonen, H.: Responses of brain neurochemistry to levodopa treatment in Parkinson's disease. In Advances in Neurology, Vol. 24, ed. L.J. Poirier., T.L. Sourkes. and P.J. Bedard. Raven Press, New York, pp. 259-274, 1979.

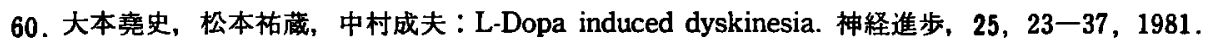

61. 宇野正威：錐体外路系の機能的解剖学. 神経精神薬理. 10, 679-689, 1981.

62. Friegyesi, T.L. and Rabin, A.:: Basal ganglia-diencephalon synaptic relations in the cat 33. An intracellular study of ansa lenticularis, lenticular fasciculus and pallido- subthalamic projection activities. Brain Res. 35, 67-87, 1971. 


\title{
Study of the neural pathway concerned with the non-rhythmic involuntary movements in cats \\ Yoshikazu YosHIMURA \\ Department of Neurological Surgery, Okayama University Medical School
}

\author{
(Director: Prof. A. Nishimoto)
}

An electrode was implanted to stimulate unilaterally the mesencephalic ventromedial tegmentum (VMT) in 27 adult cats. Abnormal involuntary movements (AIM) such as contraversive head turning, bucco-lingual movements and choreoathetoid movements of the contralateral forelimb were elicited by high frequency electrical stimulation (20$100 \mathrm{~Hz}$ ); the cats were unrestrained. Such AIM were abolished by damaging the thalamic ventrolateral nucleus ipsilateral to the stimulated side.

In order to investigate the neural pathway related to AIM, kainic acid $(2 \mu \mathrm{g})$ was injected stereotaxically into either the caudate nucleus or the globus pallidus in cats which had AIM during electrical stimulation of the VMT. These experimentally produced AIM did not changed with injection of kainic acid into the ipsilateral anteroventral part of the caudate uncleus, but were abolished by injection either into the ipsilateral rostromedial part of the caudate nucleus or into the globus pallidus. It was confirmed histologically that the intracerebral microinjection of kainic acid produced degeneration of nerve cell bodies and dendrites near the injection site while not af fecting axons terminating in or passing through it.

These results suggest that the neural pathway arising from the substantia nigra and leading to the ventrolateral thalamus via the rostromedial part of the caudate nucleus and the globus pallidus are essential in producing AIM by electrical stimulation of VMT, and that this neural pathway contains at least one synapse each within the caudate nucleus and the globus pallidus. 